\title{
Influence of Trust on Social Commercial Behavior - Taking WeChat as an Example
}

\author{
Shuo Liu* \\ Guangzhou Daily, Guangzhou 510000, China \\ *Corresponding author: Shuo Liu, 704616264@qq.com
}

\begin{abstract}
The development of science and technology as well as the internet have brought changes to our daily lives. In addition, with the widespread use of social media, more and more people are using social platforms to connect with colleagues and serve business activities. This study takes WeChat, a specific social media platform in China, as an example to study how personal social relations influence personal consumption behaviour in the digital media era through WeChat users' daily use experience. This study adopts a mixed method. First, it tests users' perception based on cognitive and emotional factors through 122 questionnaire surveys. Then, the users' experiences from their participation in social enterprises are gathered through 10 semi-structured interviews, and subsequently, the relationship between personal relations and social enterprises are analyzed. Finally, after data collation and analysis, it can be concluded that trust is the core relationship quality and also the basis for promoting the development of social business activities. At the same time, since social business activities rely on social relations, the development of swift guanxi is conducive to the realization of repurchase behaviours in social business relations.
\end{abstract}

Keywords: Social media; Trust; Relationship; WeChat; S-commercial

Publication date: August 2021; Online publication: August 30, 2021

\section{Introduction}

Social networks have changed the way we communicate in recent years, where social media customers are known as users ${ }^{[1]}$. Due to the function of information sharing, social media sites fundamentally change social consumer behavior, evaluate products through social media software, and discuss product performance through social relations ${ }^{[2]}$. The word "relationship" in the Chinese culture, which refers to the close connection between two or more individuals, is equivalent to social networking in order to form mutually beneficial interaction ${ }^{[3]}$. Research have shown that under the age of digital media, social business development is closely related to interpersonal relationships. Research have suggested that social media network building plays a positive role in social business ${ }^{[4,5]}$, but on the other hand, due to the fact that social businesses have certain transactions, the motives of social business in regard to trust and reputation may be affected ${ }^{[6]}$.

In mainland China, WeChat, the most widely used social media platform, has more than 1 billion users worldwide on a daily basis. The platform enables us to have a new understanding of the relationship between social businesses and interpersonal relationships. The purpose of this study is to explore how interpersonal relationships affect social businesses in the digital age as well as the influencing factors.

\section{Literature review}

As the largest market of online commerce in the world, in China, e-commerce accounts for more than $10 \%$ of the actual retail commerce, which serves as the market foundation for social commerce ${ }^{[4]}$. Moreover, 
the convenient function of mobile payment on WeChat provides a convenient channel for social commerce on the basis of social networking ${ }^{[7,8]}$.

Some scholars believe that consumers can share and look for products through social media platforms while making use of the payment function on social media platforms to purchase products. This further deepens the convenience of online shopping and provides a new development direction for the lifestyle in the new era ${ }^{[9]}$.

Wang and Zhang ${ }^{[5]}$ summarized and discussed the evolution of social commerce by determining the changes in social commerce from 2005 to 2011, thus proving that social commerce has become a successful business strategy and development model. However, most social commerce exists in online social platforms, which lacks the feeling of face-to-face contact. The cognition of social commerce relies on user-generated content in social relations, which includes the emotional evaluation of users on social contacts and the cognitive state of social commerce ${ }^{[10]}$.

Based on trust, online trading platforms and private sellers encourage consumers to recommend products or brand contact information to their contacts through online social platforms. Another manifestation of relationship quality is the rapidity of the relationship (swift guanxi). It can be said that swift guanxi is the development and continuation of traditional relationships, which usually exists in ecommerce platforms and online social markets. It is a form of interpersonal relationship, in which the rapid trust between two parties through social media platforms results in rapid travel ${ }^{[11]}$. Some studies have shown that the degree of trust in these kinds of relationships is positively correlated with the success of social commerce whereby the higher the degree of trust, the higher the probability of social commerce success ${ }^{[12]}$. Different from the relationships in traditional e-commerce, the power of swift guanxi in social commerce is always in the hands of the users; that is to say, users have independent rights of whether to promote swift guanxi, and they are not subjected to any other third-party constraints ${ }^{[13]}$. Based on the above literature review, the research question (RQ) is raised.

RQ: How does trust affect social commercial?

\section{Methodology}

First of all, this research has chosen network questionnaire as the quantitative research method, aiming to sort out and summarize the collected data through counting and amount of information. Through the collection of the questionnaire data, the cognition of WeChat users on social business behavior is demonstrated. Since a single method may not be able to completely solve the complexity of social research problems, it has been found that the quantitative data could only reflect the influence of trust on social business intention in terms of relationship quality, but the connection between swift guanxi and social business is not obvious. Therefore, based on the quantitative research, this study added a group of semistructured interviews and analyzed further through the interviewees' description of specific cases. This mixed-method approach allows researchers to take advantage of it to improve reliability. As the most widely used social media platform in mainland China, WeChat, which is also the focus of social commerce development, is chosen as the main platform of this study. In order to better collect data and information, this research did not only published job advertisements on my personal WeChat platform but also on the platforms of my friends and family, which reached a total of 100 people. From the 100 participants, 10 participants have been further selected for semi-structured interviews.

\section{Conclusion}

This study investigated users to determine the connection between interpersonal relationships and social business, in which the investigation was on an actual platform, WeChat. A cognitive analysis was adopted to determine the relation of rapid trust and its impact on social business. As a platform provides a new way of thinking, social business participants were included to further explore the influence of interpersonal 
relationship and social business. This research adopted a mixed research method, developed an online questionnaire and a semi-structured interview for WeChat users, adopted a simple sampling method, and solved the research problem by investigating the users' understanding of the connection between interpersonal relationships and social business.

Trust, on the other hand, is an essential and critical element in social commerce. A majority of the participants mentioned that it is precisely because of trust that they would choose to use social platforms for both, buying and selling. In this study, the focus on the implementation of social business is inadequate to explore the relationship between trust and social business repurchase, thus this aspect still requires more theoretical research to comb and perfect it. Another limitation is in regard to the survey sample. The sample selected was inadequate in representing the user attributes of the whole social business platform due to convenience sampling. Hence, in this way, the study has a certain one-sidedness. Previous studies have mainly contributed to the relationship between the relationship quality and social business. This study further dwelt in this aspect, focusing on the direction of trust and swift guanxi to extend social business activities, and provided suggestions for social business participants to maintain swift guanxi in the future.

\section{Disclosure statement}

The author declares that there is no conflict of interest.

\section{References}

[1] Fisher E, 2015, You Media: Audience as Marketing in Social Media. Media, Culture \& Society, 37(1): 50-67. Doi: 10.1177/0163443714549088

[2] Baethge C, Klier J, Klier M, 2016, Social Commerce - State-of-the-Art and Future Research Directions. Electronic Markets, 26(3): 269-90.

[3] Shao Z, Pan Z, 2019, Building Guanxi Network in the Mobile Social Platform: A Social Capital Perspective. International Journal of Information Management, 44: 109-20.

[4] Niedermeier KE, Wang E, Zhang X, 2016, The Use of Social Media among Business-to-Business Sales Professionals in China. Journal of Research in Interactive Marketing, 10(1): 33-49.

[5] Wang C, Zhang P, 2012, The Evolution of Social Commerce: The People, Management, Technology, and Information Dimensions. Communications of the Association for Information Systems, 31(1): 5.

[6] Martinsons MG, 2008, Relationship-Based E-Commerce: Theory and Evidence from China. Information Systems Journal, 18(4): 331-56.

[7] Cormack M, 2015, WeChat's Impact: A Report on WeChat Platform Data. Technode. https://technode.com/2015/02/10/wechat-impact-report/ (accessed on August 15, 2016).

[8] Chen Y, Lu Y, Wang B, et al., 2019, How Do Product Recommendations Affect Impulse Buying? An Empirical Study on WeChat Social Commerce. Information \& Management, 56(2): 236-48.

[9] Kim S, Park H, 2012, Effects of Various Characteristics of Social Commerce (S-Commerce) On Consumers' Trust and Trust Performance. International Journal of Information Management, 33(2): 318-32.

[10] Eroglu SA, Machleit KA, Davis LM, 2003, Empirical Testing of a Model of Online Store Atmospherics and Shopper Responses. Psychology \& Marketing, 20(2): 139-50.

[11] Lin J, Luo Z, Cheng X, et al., 2019, Understanding the Interplay of Social Commerce Affordances and Swift Guanxi: An Empirical Study. Information \& Management, 56(2): 213-24.

[12] Fan J, Zhou W, Yang X, et al., 2019, Impact of Social Support and Presence on Swift Guanxi and Trust 
in Social Commerce. Industrial Management \& Data Systems, 119(9):2033-54.

[13] Yang X, 2019, Consumers' Decisions in Social Commerce: The Role of Guanxi Elements. Asia Pacific Journal of Marketing and Logistics, 31(4): 759-72.

[14] Acharya AS, Prakash A, Saxena P, et al., 2013, Sampling: Why and How of It. Indian Journal of Medical Specialties, 4(2): 330-3.

[15] Aïmeur E, Schönfeld D, 2011, The Ultimate Invasion of Privacy: Identity Theft, 9th International Conference on Privacy, Security and Trust (PST), Montréal, 24-31.

[16] Baker J, Parasuraman A, Grewal D, et al., 2002, The Influence of Multiple Store Environments Cues on Perceived Merchandise Value and Patronage Intentions. Journal of Marketing, 66(2): 120-41.

[17] Beisel D, 2006, The Emerging Field of Social Commerce and Social Shopping. GenuineVC: David Beisel's Perspective on Digital Change. http://www.crowdstorm.co.uk/blog/the-emergingfield-ofsocial-commerce- and-social-shopping (updated September 21, 2012).

[18] Bhattacherjee A, 2012, Social Science Research: Principles, Methods, and Practices, Scholar Commons, : 137-9.

[19] Carroll B, 2008, Social Shopping: A New Twist on e-Commerce. Furniture Today, 81. http://www.furnituretoday.com/article/44463-Social_shopping_A_new_twist_on_e_commerce.php (updated September 21, 2012).

[20] Chen XP, Chen CC, 2004, On the Intricacies of the Chinese Guanxi: A Process Model of Guanxi Development. Asia Pacific Journal of Management, 21(3): 305-24.

[21] Clawson T, 2008, Putting a Price on Online Friendships, Revolution, 54-7.

[22] Comscore, 2010, SNS Reach a Higher Percentage of Women Than Men Worldwide, Boston, MA: ComScore.

[23] Crosby LA, Evans KR, Cowles D, 1990, Relationship Quality in Services Selling: An Interpersonal Influence Perspective. Journal of Marketing, 54(3): 68-81.

[24] Debei MM, Akroush MN, Ashouri MI, 2015, Consumer Attitudes Towards Online Shopping: The Effects of Trust, Perceived Benefits, and Perceived Web Quality. Internet Research, 25(5): 707-33.

[25] Farivar S, Turel O, Yuan Y, 2017, A Trust-Risk Perspective on Social Commerce Use: An Examination of the Biasing Role of Habit. Internet Research, 27(3): 586-607.

[26] Ha HY, John J, John JD, et al., 2016, Temporal Effects of Information from Social Networks on Online Behaviour: The Role of Cognitive and Affective Trust. Internet Research, 26(1): 213-35.

[27] Hsu MH, Chuang LW, Hsu CS, 2014, Understanding Online Shopping Intention: The Roles of Four Types of Trust and Their Antecedents. Internet Research, 24(3): 332-52.

[28] Kaplan AM, Haenlein M, 2010, Users of the World, Unite! The Challenges and Opportunities of Social Media. Business Horizons, 53(1): 59-68.

[29] Kooser AC, 2008, Social Shopping. Entrepreneur. http://www.pcworld.com/businesscenter/article/148 516/social_shopping.html (updated September 21, 2012).

[30] Leung WK, Shi S, Chow WS, 2019, Impacts of User Interactions on Trust Development in C2C Social Commerce. Internet Research, 30(1): 335-56.

[31] Liang TP, Turban E, 2011, Introduction to the Special Issue of Social Commerce: A Research Framework for Social Commerce. International Journal of Electronic Commerce, 16(2): 5-14.

[32] Lien CH, Cao Y, Zhou X, 2017, Service Quality, Satisfaction, Stickiness, and Usage Intentions: An Exploratory Evaluation in the Context of WeChat Services. Computers in Human Behavior, 68: 403- 
10.

[33] McKnight DH, Choudhury V, Kacmar C, 2002, Developing and Validating Trust Measures for ECommerce: An Integrative Typology. Information Systems Research, 13(3): 334-59.

[34] Palmatier RW, Dant RP, Grewal D, et al., 2006, Factors Influencing the Effectiveness of Relationship Marketing: A Meta-Analysis. Journal of Marketing, 70(4): 136-53.

[35] Parise S, Guinan PJ, 2008, Proceedings of the 41 st Annual Hawaii International Conference on System Sciences (HICSS 2008), January 7-10, 2008: Marketing Using Web 2.0. Waikoloa, HI, USA, 281.

[36] Portal EG, 2018, GDPR Key Changes-An Overview of the Main Changes Under GDPR and How They Differ from the Previous Directive.

[37] Schreuder HT, Gregoire TG, Weyer JP, 2001, For what Applications Can Probability and NonProbability Sampling Be Used?. Environmental Monitoring and Assessment, 66(3): 281-91.

[38] Shabbir H, Palihawadana D, Thwaites D, 2007, Determining the Antecedents and Consequences of Donor-Perceived Relationship Quality - A Dimensional Qualitative Research Approach. Psychology \& Marketing, 24(3): 271-93.

[39] Shankar V, Urban GL, Sultan F, 2002, Online Trust: A Stakeholder Perspective, Concepts, Implications, and Future Directions. The Journal of Strategic Information Systems, 11(3/4): 325-44.

[40] Shareef MA, Dwivedi YK, Kumar V, et al., 2018, Purchase Intention in an Electronic Commerce Environment: A Trade-Off Between Controlling Measures and Operational Performance. Information Technology and People, 32(6): 1345-75.

[41] Shin DH, 2013, User Experience in Social Commerce: In Friends We Trust. Behaviour \& Information Technology, 32(11): 1191-2.

[42] Szeto R, Wright PC, Cheng E, 2006, Business Networking in the Chinese Context. Management Research News, 29(7): 425-38.

[43] Turel O, Yuan Y, Connelly CE, 2008, Injustice We Trust: Predicting User Acceptance of E-Customer Services. Journal of Management Information Systems, 24(4): 123-51.

[44] Webber SS, Klimoski RJ, 2004, Client-Project Manager Engagements, Trust, and Loyalty. Journal of Organizational Behavior: The International Journal of Industrial, Occupational and Organizational Psychology and Behavior, 25(8): 997-1013.

[45] Wigand RT, Benjamin RI, Birkland JL, 2008, Proceedings of the 10th International Conference on Electronic Commerce, August 19-22, 2008: Web 2.0 and Beyond: Implications for Electronic Commerce. ACM Press the 10th International Conference, Innsbruck, Austria, 1-5.

[46] Zhao L, Lu Y, Wang B, et al., 2012, Cultivating the Sense of Belonging and Motivating User Participation in Virtual Communities: A Social Capital Perspective. International Journal of Information Management, 32(6): 574-88. 